\title{
Genes and Antigens Controlling Tumor Metastases*
}

\author{
L. Eisenbach and M. Feldman
}

\section{A. Introduction}

The generation of metastases by neoplastic cells constitutes the main problem in tumor malignancy. Metastasis is a multistep process, in which each of the sequential steps is controlled by different properties of the disseminating tumor cells. The host's capacity to recognize metastatic, as against nonmetastatic, cells of the tumor cell population could exert a controlling effect on each of the stages culminating in the progressive growth of metastases. Recognition of cellsurface antigenic epitopes on metastatic cells via $\mathrm{T}$ lymphocytes would be restricted by cell-surface class 1 glycoproteins coded by the major histocompatibility complex (MHC). In mice, such glycoproteins are coded by the $H-2 D$ and $H-2 K$ genes of the $\mathrm{MHC}$, and differences in their expression on metastatic, as distinct from nonmetastatic, cells of a given tumor could therefore elicit different $T$ cell effector responses, which would then determine the fate of the disseminating tumor cells. The feasibility of an MHC control of the metastatic process attracted us during investigations of the unique properties of a metastatic carcinoma originated in a C57BL $\left(H-2^{b}\right)$ mouse, the 3LL Lewis lung carcinoma. Following transplantation in syngeneic animals, the 3LL carcinoma generates spontaneous lung metastases while growing locally at any site of transplantation. However, this tumor differs from all normal tissues and from many other tumors in its ca-

* Department of Cell Biology, The Weizmann Institute of Science, Rehovot 76100, Israel pacity to grow in allogeneic recipients. Yet, metastases were generated only when the tumor grew in syngeneic animals [1]. The allograft response elicited by the local tumor could not arrest the local growth, but was sufficiently powerful to prevent the growth of metastatic lung nodules. Subsequent experiments indicated that the spontaneous lung metastases behaved as "secondary" grafts, being rejected by the alloreactive $\mathrm{T}$ cells that had been elicited by the local graft [2]. When the 3LL cells were injected intravenously to similar allogeneic mice, lung tumors developed as "primary" grafts and these did grow progressively [2]. It thus appeared that in an allogeneic recipient the local tumor can resist an immune response, which prevents the growth of its spontaneous lung metastases. This raised the question as to whether an immune response elicited by the growing local tumor in syngeneic recipients could similarly prevent the progression of spontaneous metastases in syngeneic animals and whether the probability of forming metastases by individual tumor cells grown in syngeneic mice is a function of their immunogenic properties, which in turn might be a function of the expression of the restricting class $1 \mathrm{MHC}$ antigens on the neoplastic cells.

\section{B. The Relative Expression of $\mathbf{H}-2 K^{b} /$ H-2Db on Clones of the 3LL Tumor is Correlated with Their Metastatic Competence}

Our approach to the question as to whether differences in the expression of $\mathrm{H}-2 \mathrm{D}^{\mathrm{b}}$ ver- 
Table 1. Metastases and $\mathrm{H}-2$ expression of $3 \mathrm{LL}$ subclones

\begin{tabular}{|c|c|c|c|c|c|c|c|c|}
\hline \multirow[t]{3}{*}{ Clone } & \multicolumn{4}{|c|}{ Percent positive cells ${ }^{a}$} & \multicolumn{2}{|c|}{ Ratio $K^{b} / D^{b}$} & \multicolumn{2}{|c|}{ Lung weight (mg) } \\
\hline & \multicolumn{2}{|l|}{ Gain 4} & \multicolumn{2}{|l|}{ Gain 8} & \multirow[t]{2}{*}{ Gain 4} & \multirow[t]{2}{*}{ Gain 8} & \multirow[t]{2}{*}{ Mean } & \multirow[t]{2}{*}{ Range } \\
\hline & $\mathrm{K}^{\mathrm{b}}$ & $\mathrm{D}^{\mathrm{b}}$ & $\mathrm{K}^{\mathrm{b}}$ & $\mathrm{D}^{\mathrm{b}}$ & & & & \\
\hline A9A5 & $1 \pm 0$ & $1 \pm 0$ & $5 \pm 0$ & $5 \pm 0$ & 1.0 & 1.0 & $243 \pm 58$ & $126-361$ \\
\hline A9FH5 & $2 \pm 2$ & $2 \pm 3$ & $6 \pm 4$ & $8 \pm 3$ & 1.0 & 0.75 & $217 \pm 35$ & $163-271$ \\
\hline A9FJ1 & $3 \pm 1$ & $4 \pm 1$ & $13 \pm 2$ & $15 \pm 2$ & 0.75 & 0.87 & $230 \pm 62$ & $187-378$ \\
\hline A9C3 & $11 \pm 3$ & $25 \pm 6$ & $33 \pm 6$ & $60 \pm 15$ & 0.44 & 0.55 & $233 \pm 25$ & $195-273$ \\
\hline A9E2 & $13 \pm 6$ & $28 \pm 8$ & $43 \pm 9$ & $55 \pm 18$ & 0.46 & 0.78 & $220 \pm 41$ & $172-278$ \\
\hline A9G3 & $10 \pm 6$ & $31 \pm 10$ & $35 \pm 10$ & $54 \pm 16$ & 0.32 & 0.65 & $229 \pm 27$ & $180-263$ \\
\hline A9H3 & $14 \pm 4$ & $26 \pm 11$ & $30 \pm 4$ & $42 \pm 9$ & 0.54 & 0.71 & $224 \pm 21$ & $178-237$ \\
\hline A9H6 & $16 \pm 5$ & $53 \pm 15$ & $40 \pm 13$ & $67 \pm 14$ & 0.30 & 0.60 & $236 \pm 91$ & $174-478$ \\
\hline A9J2 & $16 \pm 6$ & $37 \pm 9$ & $53 \pm 10$ & $73 \pm 14$ & 0.43 & 0.73 & $218 \pm 28$ & $185-264$ \\
\hline A9FA1 & $22 \pm 6$ & $37 \pm 10$ & $45 \pm 2$ & $55 \pm 12$ & 0.59 & 0.82 & $192 \pm 28$ & $145-227$ \\
\hline A9FA6 & $16 \pm 4$ & $37 \pm 0$ & $43 \pm 8$ & $70 \pm 4$ & 0.43 & 0.61 & $208 \pm 14$ & $182-224$ \\
\hline A9FI1 & $9 \pm 3$ & $21 \pm 8$ & $35 \pm 9$ & $47 \pm 12$ & 0.43 & 0.74 & $201 \pm 18$ & $180-239$ \\
\hline $\mathrm{A} 9 \mathrm{FJ} 2$ & $14 \pm 0$ & $65 \pm 0$ & $47 \pm 0$ & $87 \pm 0$ & 0.22 & 0.54 & $236 \pm 30$ & $193-273$ \\
\hline A9FJ3 & $18 \pm 7$ & $50 \pm 10$ & $44 \pm 16$ & $75 \pm 18$ & 0.36 & 0.59 & $214 \pm 31$ & $183-278$ \\
\hline 3LLFI6 & $23 \pm 5$ & $30 \pm 3$ & $61 \pm 11$ & $61 \pm 6$ & 0.70 & 1.0 & $219 \pm 39$ & $173-290$ \\
\hline A9E6 & $11 \pm 6$ & $47 \pm 2$ & $34 \pm 9$ & $84 \pm 8$ & 0.24 & 0.40 & $259 \pm 73$ & $215-458$ \\
\hline A9L2 & $14 \pm 0$ & $69 \pm 0$ & $42 \pm 0$ & $89 \pm 0$ & 0.20 & 0.47 & $284 \pm 23$ & $252-320$ \\
\hline A9FE2 & $5 \pm 2$ & $23 \pm 16$ & $14 \pm 6$ & $45 \pm 16$ & 0.22 & 0.31 & $367 \pm 300$ & $233-1159$ \\
\hline 3LLFA5 & $9 \pm 9$ & $51 \pm 20$ & $25 \pm 9$ & $63 \pm 13$ & 0.18 & 0.40 & $310 \pm 188$ & $204-767$ \\
\hline 3LLFL1 & $14 \pm 8$ & $35 \pm 10$ & $30 \pm 41$ & $57 \pm 13$ & 0.40 & 0.53 & $294 \pm 159$ & $185-588$ \\
\hline A9FG6 & $7 \pm 3$ & $43 \pm 17$ & $15 \pm 7$ & $71 \pm 23$ & 0.16 & 0.21 & $429 \pm 395$ & $205-1311$ \\
\hline A9FJ4 & $7 \pm 3$ & $29 \pm 9$ & $14 \pm 7$ & $56 \pm 19$ & 0.24 & 0.25 & $451 \pm 361$ & $168-1355$ \\
\hline 3LLFA3 & $2 \pm 0$ & $41 \pm 10$ & $11 \pm 6$ & $56 \pm 18$ & 0.05 & 0.20 & $437 \pm 347$ & $175-1226$ \\
\hline 3LLFB4 & $8 \pm 7$ & $45 \pm 10$ & $15 \pm 7$ & $61 \pm 10$ & 0.18 & 0.25 & $947 \pm 243$ & $662-1409$ \\
\hline 3LLFC1 & $6 \pm 0$ & $87 \pm 0$ & $22 \pm 0$ & $96 \pm 0$ & 0.07 & 0.23 & $641 \pm 220$ & $486-1073$ \\
\hline 3LLFC6 & $7 \pm 2$ & $32 \pm 15$ & $11 \pm 8$ & $47 \pm 17$ & 0.13 & 0.23 & $492 \pm 224$ & $336-1226$ \\
\hline 3LLFL5 & $2 \pm 3$ & $42 \pm 13$ & $9 \pm 6$ & $62 \pm 12$ & 0.05 & 0.15 & $567 \pm 387$ & $193-1290$ \\
\hline 3LLFL6 & $4 \pm 4$ & $26 \pm 6$ & $6 \pm 5$ & $52 \pm 13$ & 0.15 & 0.12 & $662 \pm 367$ & $233-1158$ \\
\hline 3LLFM2 & $4 \pm 3$ & $28 \pm 7$ & $19 \pm 8$ & $72 \pm 8$ & 0.14 & 0.26 & $518-191$ & $236-735$ \\
\hline
\end{tabular}

a Tumor cells $2-4 \times 10^{6}$ were incubated at $4^{\circ} \mathrm{C}$ for $30 \mathrm{~min}$ in purified anti- $\mathrm{K}^{\mathrm{b}}$ (28-13-3) monoclonal antibody or anti- $\mathrm{D}^{\mathrm{b}}(28-14-8)$ antibody, washed twice in phosphate-buffered saline with $1 \%$ bovine serum albumin and $0.2 \%$ sodium azide, and reincubated in fluorescein isothiocyanate-labeled rabbit anti-mouse Ig. Fluorescence-activated cell sorter II analysis was performed with photomultiplier tube set at $550 \mathrm{~V}$

b In $10 \mathrm{C} 57 \mathrm{BL} / 6 \mathrm{~J}$ male mice, $10^{5}$ cells were inoculated i.f.p. When the primary tumors reached $8 \mathrm{~mm}$ in diameter tumor-bearing legs were amputated. Metastatic load was determined 30 days after amputation

sus $\mathrm{H}-2 \mathrm{~K}^{\mathrm{b}}$ glycoproteins (the class 1 antigens of the mouse MHC) control the metastatic potency of 3LL cells was triggered by earlier experiments in our laboratory. In these we aimed at determining the minimum genetic identities between the tumor strain of origin and the host's phenotype that are required for the generation of me- tastases. We found that identities at the $H-2 D^{b}$ gene and the non-MHC background are sufficient for metastasis formation, whereas the $\mathrm{H}-2 \mathrm{~K}$ phenotype of the recipient was completely irrelevant [1]. It then turned out that identity at the $\mathrm{H}-2 \mathrm{~K}^{\mathrm{b}}$ was unnecessary, because the 3LL tumor hardly expressed the $\mathrm{H}-2 \mathrm{~K}^{\mathrm{b}}$ on its cell surface [3]. 
Table 2. The effect of interferon and retinoic acid on MHC cell surface expression and metastasis

\begin{tabular}{|c|c|c|c|c|c|}
\hline \multirow[t]{2}{*}{ Treatment } & \multicolumn{4}{|c|}{ Antibody binding $\left(\mathrm{cpm} / 10^{4} \text { cells }\right)^{\mathrm{a}}$} & \multirow{2}{*}{$\begin{array}{l}\text { Spontaneous } \\
\text { metastases: } \\
\text { Lung wt } \\
(\mathrm{mg} \pm \mathrm{SD})\end{array}$} \\
\hline & $\begin{array}{l}\text { Anti-K } \mathbf{K}^{\mathbf{b}} \\
28-13-3\end{array}$ & $\begin{array}{l}\text { Anti-K } K^{b} \\
20-8-4\end{array}$ & $\begin{array}{l}\text { Anti-D } \\
28-14-8\end{array}$ & $\begin{array}{l}\mathrm{K}^{\mathrm{b}}-\mathrm{D}^{\mathrm{b}} \\
(28-13-3 / \\
28-14-8)\end{array}$ & \\
\hline \multicolumn{6}{|l|}{ A9 clone } \\
\hline- & $13028 \pm 1022$ & $25529 \pm 402$ & $17224 \pm 1441$ & 0.76 & $249 \pm 66$ \\
\hline Interferon & $23854 \pm 1214$ & $55141 \pm 4342$ & $77424 \pm 2218$ & 0.31 & $410 \pm 205$ \\
\hline Retinoic acid & $12518 \pm 853$ & $22276 \pm 1524$ & $48537 \pm 983$ & 0.26 & $519 \pm 270$ \\
\hline \multicolumn{6}{|l|}{ D122 clone } \\
\hline- & $2610 \pm 123$ & $3300 \pm 211$ & $13200 \pm 459$ & 0.20 & $536 \pm 176$ \\
\hline Interferon & $5329 \pm 327$ & $6500 \pm 259$ & $44000 \pm 1320$ & 0.12 & $794 \pm 236$ \\
\hline Retinoic acid & $1958 \pm 73$ & $2800 \pm 322$ & $12800 \pm 924$ & 0.15 & $620 \pm 178$ \\
\hline
\end{tabular}

Treatment was performed with $10^{5}$ tissue culture-propagated cells transferred to $100-\mathrm{mm}$ petri dishes in $10 \mathrm{ml}$ Dulbecco's modified Eagle's medium supplemented with $10 \%$ fetal calf serum (FCS), $1 \%$ glutamine, $1 \%$ sodium pyruvate, $1 \%$ nonessential amino acids, and $1 \%$ antibiotics in the presence of 100 units $/ \mathrm{ml}$ interferon ( $\alpha$ and $\beta, 10^{7}$ units $/ \mathrm{mg}$ ) or $10^{-6} \mathrm{~mol} / \mathrm{liter}$ retinoic acid. The cells were grown to confluency ( 1 week), with twice-weekly changes of growth medium

a Direct radioimmunoassay: $10^{6}$ living cells were incubated with $50 \mu 1{ }^{125}$ I-labeled antibody, 0.1-1.5 $\mu \mathrm{g}$ protein A-Sepharose-purified (28-14-8 and 20-8-4), or 0.5-7.5 $\mu \mathrm{g}$ semipurified antibody (28-13-3). Binding was done for $1 \mathrm{~h}$ at $4^{\circ} \mathrm{C}$ in a $300-\mu \mathrm{l}$ final volume of phosphate-buffered saline (PBS), 5\% FCS, after which plates (24 wells) were washed four times in PBS-FCS and cells were collected into tubes and monitored in a gamma counter. The saturation values of a dose-dependence curve are given

The question which thus arose was whether the absence of $\mathrm{H}-2 \mathrm{~K}^{\mathrm{b}}$ expression concomitant with the presence of $H-2 D^{b}$ determined the metastatic potency of the tumor cell population. To answer this question we cloned 3LL cells in soft agar and tested the metastatic potency of individual clones. We found that the clones differ in their capacity to generate spontaneous lung metastases when grown intrafootpad (i.f.p.) in syngeneic animals. As previously demonstrated for other tumors [4], this tumor cell population varied in the metastatic potency of its individual cells. To test whether there is a correlation between the metastatic properties of individual clones and the expression of MHC genes, we used monoclonal antibodies 28-13-3 and 20-8-4, which identify $\mathrm{H}-2 \mathrm{~K}^{\mathrm{b}}$ molecules, and antibody $28-14-8$, which identifies $\mathrm{H}-2 \mathrm{D}^{\mathrm{b}}$ molecules [5]. We analyzed 30 clones by direct radioimmunoassay and with the fluorescence-activated cell sorter. We found (Table 1) that the lower the $H-2 K^{b} / H-2 D^{b}$ ratio, the higher was the metastatic potential of the cloned cells [6].

\section{Induced Alterations of H-2K/H-2D Ratio Alters the Metastatic Phenotype}

To examine whether the relative expression of class 1 antigens of the MHC was causally related to its metastatic phenotype, we attempted to alter the $\mathrm{H}-2 \mathrm{~K}^{\mathrm{b}} / \mathrm{H}-2 \mathrm{D}^{\mathrm{b}}$ ratio, and then to test whether such alteration will change the metastatic potency of the cells. For this purpose we treated in vitrocloned tumor cells with either interferon $\alpha+\beta$ (a stimulator of $\mathrm{H}-2$ synthesis) or with retinoic acid. Cells of two clones were used in these experiments: The low metastatic A9 clone that expresses both the $\mathrm{H}-2 \mathrm{~K}$ and the H-2D glycoproteins, and the highmetastatic D122 clone that expresses the $\mathrm{H}-2 \mathrm{D}^{\mathrm{b}}$ molecules but lacks $\mathrm{H}-2 \mathrm{~K}^{\mathrm{b}}$ expression. It was found that interferon caused an increase in both $\mathrm{K}$ and $\mathrm{D}$ expression of both A9 and D122 cells, yet the net increase in $H-2 D^{b}$ expression was significantly higher than that of $\mathrm{H}-2 \mathrm{~K}^{\mathrm{b}}$ expression, thus lowering the $\mathrm{H}-2 \mathrm{~K} / \mathrm{H}-2 \mathrm{D}$ ratio (Table 2). These changes were associated 


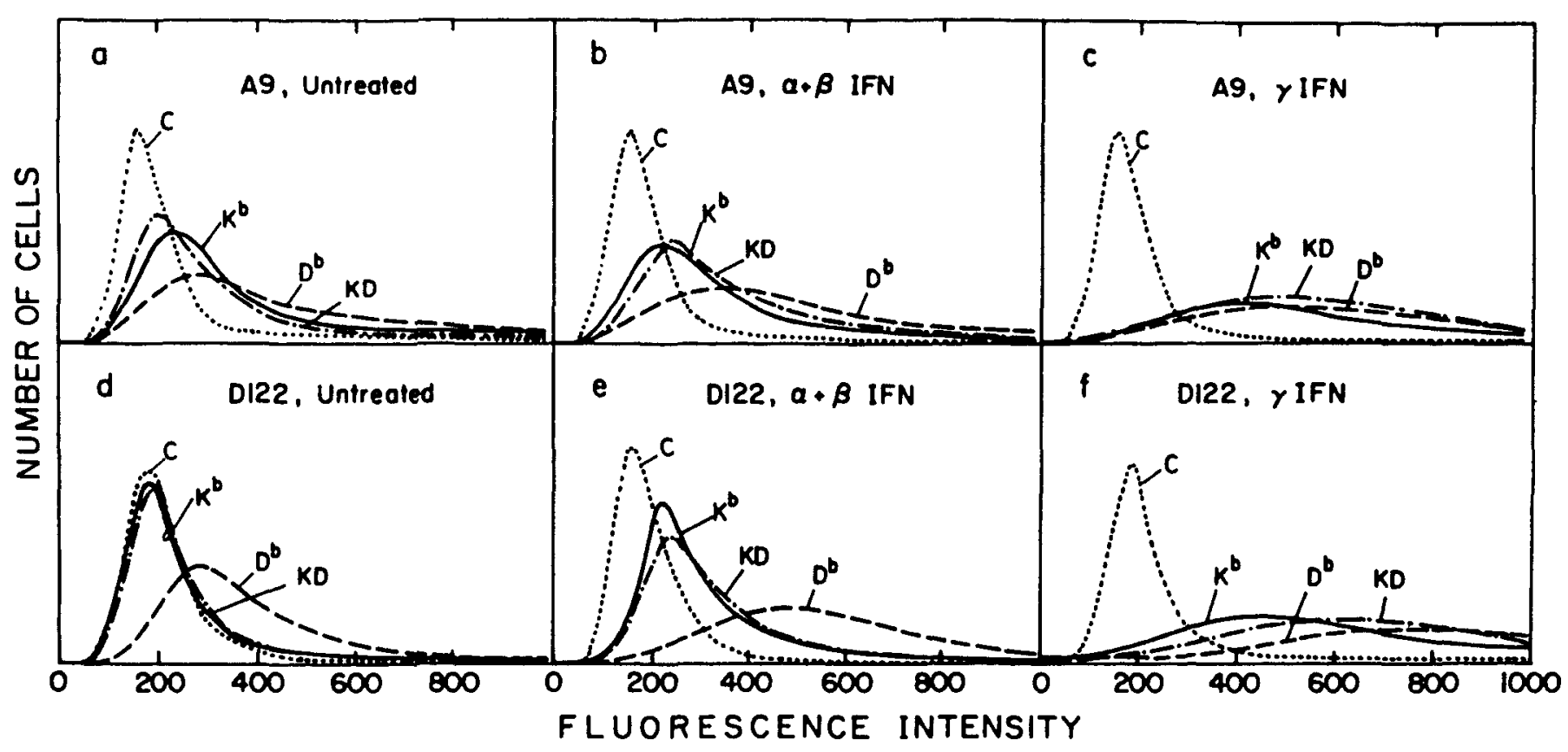

Fig. 1a-f. Effect of interferons on cell surface expression of $\mathrm{H}-2 \mathrm{~K}^{\mathrm{b}}$ and $\mathrm{H}-2 \mathrm{D}^{\mathrm{b}}$ alloantigens of clones A9 and D122. Quantities of $2 \times 10^{5}$ tissue culture-propagated cells were transferred to 100 $\mathrm{mm}$ petri dishes in $10 \mathrm{ml}$ Dulbecco's modified Eagle's medium supplemented with $10 \%$ fetal calf serum, $1 \%$ glutamine, $1 \%$ sodium pyruvate, $1 \%$ nonessential amino acids, and $1 \%$ antibiotics. The cells were grown for 5 days in the presence of no interferon (a, d); interferon $\alpha+\beta 500$ units/ $\mathrm{ml}, \quad 10^{7}$ units $/ \mathrm{mg} \quad(\mathbf{b}, \quad \mathbf{e}) ; \quad$ or $\gamma$-interferon 100 units $/ \mathrm{ml}, 12 \times 10^{7}$ units $/ \mathrm{mg}(\mathbf{c}, \mathbf{f})$. Cells were treated with monoclonal antibody 28-13-3 (anti$\mathrm{K}^{\mathrm{b}}$ ), 20-8-4 (anti-K ${ }^{\mathrm{b}} \mathrm{D}^{\mathrm{b}}$, reacts mainly with $\mathrm{K}^{\mathrm{b}}$ molecules), or 28-14-8 (anti-D ${ }^{b}$ and analyzed by the FACS II

with a significant increase in the metastatic load produced by both the A9 clone and the D122 clone. Treatment with retinoic acid did not affect H-2K expression, but increased significantly $\mathrm{H}-2 \mathrm{D}^{\mathrm{b}}$ production, lowering the $\mathrm{H}-2 \mathrm{~K} / \mathrm{H}-2 \mathrm{D}$ ratio even further. This again increased the metastatic load produced by D122 cells, and converted the low metastatic A9 clone to a high metastatic phenotype (Table 2).

Thus far we have not found a chemical signal which would cause an increase in the $\mathrm{H}-2 \mathrm{~K} / \mathrm{H}-2 \mathrm{D}$ ratio and thereby effect a decrease in the metastatic potency of the cells. Very recent experiments with $\gamma$-interferon have indicated that this interferon is more effective than interferon $\alpha+\beta$ in induction of the cell surface expression of $H-2 D^{b}$ and, especially, of $\mathrm{H}-2 \mathrm{~K}^{\mathrm{b}}$ molecules on $\mathrm{A} 9$ and D122 tumor cells (Fig. 1). While testing for spontaneous lung metastases we observed no changes in the low metastatic phenotype of A9 clone and a reduction in the number of metastatic nodules formed by the high metastatic D122 clone.

\section{The Relative Expression of $\mathrm{H}-2 \mathrm{~K} / \mathrm{H}-2 \mathrm{D}$ Molecules is Correlated with the Immunogenic Properties of the Cloned Cell Populations}

We then considered whether the low $\mathrm{H}-2 \mathrm{~K} / \mathrm{H}-2 \mathrm{D}$ ratio determines a metastatic phenotype because it confers a low immunogenic potency on the neoplastic cells.

\section{Growth and Metastasis in Allogeneic Recipients}

As stated above, the parental 3LL cell population, manifesting a low $\mathrm{H}-2 \mathrm{~K} / \mathrm{H}-2 \mathrm{D}$ ratio, can grow across $\mathrm{H}-2$ barriers although metastases are not formed in allogeneic mice. We also tested whether the nonmetastatic $A 9$ clone $\left(\mathrm{K}^{+} \mathrm{D}^{+}\right)$and the D122 clone $\left(\mathrm{K}^{-} \mathrm{D}^{+}\right)$differed in their capacity to grow in allogeneic recipients. Whereas the D122 grew locally without generating metastases in BALB/c $\left(\mathrm{H}-2^{\mathrm{d}}\right)$ and $\mathrm{C} 3 \mathrm{H}\left(\mathrm{H}-2^{\mathrm{k}}\right)$ 
mice, the nonmetastatic A9 clone was rejected by allogeneic recipients [7]. The metastatic potential in syngeneic mice was thus correlated with the immunogenic effect determining growth in allogeneic mice.

\section{Growth and Metastasis in Congenic Recipients}

Clone A9 behaves as a regular incompatible immunogenic allograft in allogeneic mice. To test whether the class I antigens alone on the A9 clone could elicit rejection of the grafted tumor, $10^{5}$ A9 or D122 cells were inoculated to groups of $\mathrm{H}$-2-recombinant mice on a C57BL/10 background [7]. We used B10.HTG $\left(\mathrm{K}^{\mathrm{d}} \mathrm{D}^{\mathrm{b}}\right)$, B10.D2 $\left(K^{\mathrm{d}} \mathrm{D}^{\mathrm{d}}\right)$, and B10.A $(4 \mathrm{R})\left(\mathrm{K}^{\mathrm{k}} \mathrm{D}^{\mathrm{b}}\right)$ mice. Clone A9 $\left(K^{b} D^{b}\right)$ grew in $9 / 10$ B10.HTG mice at a slower rate than in C57BL/6J mice. Only partial and slow growth was observed in B10.D2 mice (5/ 11 ), and the $A 9$ clone grew in only one of nine mice of the $B 10 . A(4 R)$ strain. In contrast, D122 grew in C57BL/6J and in the three recombinant strains at a similar rate. Testing for metastases, we found that D122 metastasized in $\mathrm{C} 57 \mathrm{BL} / 6 \mathrm{~J} \quad\left(\mathrm{~K}^{\mathrm{b}} \mathrm{D}^{\mathrm{b}}\right)$, B10.HTG $\left(\mathrm{K}^{\mathrm{d}} \mathrm{D}^{\mathrm{b}}\right)$, and B10.A(4R) $\left(\mathrm{K}^{\mathrm{k}} \mathrm{D}^{\mathrm{b}}\right)$, but not in B10.D2 $\left(K^{d} D^{d}\right)$ mice. The $K^{b}$ positive A9 cells grew partially in recombinant mice, while D122 grew progressively and metastases were rejected only in B10.D2 $\left(D^{d}\right)$ mice. Thus, the higher immunogenic effect of clone A9, compared with the D122 clone, is a function of an immune response elicited by the $\mathrm{H}-2 \mathrm{~K}$ determinant.

III. Clone A9, Unlike Clone D122, is Immunogenic in Syngeneic Mice

In view of the differences in growth pattern of A9 and D122 clones in allogeneic and H-2-recombinant mice [7], we asked whether the higher immunogenicity of the A9 clone was also effective in the syngeneic host, and whether this could account for the inability of the A9 clone to metastasize. C57BL/6J mice were immunized by three intraperitoneal injections of $10^{7}$ irradiated $\mathrm{A} 9, \mathrm{D} 122$, or $3 \mathrm{LL}$ cells at 1 -week intervals. Ten days after the last injection, immunized mice and controls were challenged by A9 or D122 cells. We found that immunization by A9 cells significantly slowed the growth rate of a second A9 tumor but did not affect the growth rate of the metastatic D122 tumor. Immunization by clone D122 or by 3LL did not retard the growth of a second A9 or D122 tumor. Similar results were obtained when mice were intradermally immunized with living A9 or D122 cells.

IV. Cytotoxic Activity of Lymphocytes Sensitized In Vivo to A9 and D122 Tumor Cells

Following the in vivo observations, we tested the cytotoxic $\mathrm{T}$ lymphocyte (CTL) responses evoked by cells of A9 and D122 clones in syngeneic hosts. $\mathrm{C} 57 \mathrm{BL} / 6 \mathrm{~J}$ mice received $5 \times 10^{4}$ or $10^{5} \mathrm{~A} 9$ or D122 tumor cells by intradermal injection. At 12 days after the immunization, spleen cells were removed and stimulated in vitro for 5 days on monolayers of irradiated and mitomycin C-treated A9 or D122 cells. The cytotoxic activity of these spleen cells was assayed against A9 and D122 target cells in a 16-h indium-111 release assay. Figure 2 demonstrates that A9 induced high levels of cytotoxic activity, which was manifested against A9 cells and to a lesser extent against D122 target cells. D122 cells induced a lymphocyte population that manifested low cytotoxic activity against D122 or A9 target cells. Thus, the in vitro interaction of immune lymphocytes with nonmetastatic A9 cells led to the destruction of the tumor cells, whereas lymphocytes interacting with D122 cells were significantly less efficient in destroying the tumor cells.

\section{E. Molecular Nature of MHC Gene Products in 3LL Clones}

Low metastatic clones such as A9 were shown to bind anti-H-2 $\mathrm{K}^{\mathrm{b}}$ and anti-H-2D antibodies, while high metastatic clones such as D122 bound only $\mathrm{H}-2 \mathrm{D}^{\mathrm{b}}$ antibodies (Table 2). We tested the molecular similarity of the $\mathrm{MHC}$ glycoproteins to $\mathrm{H}-2^{\mathrm{b}}$ 


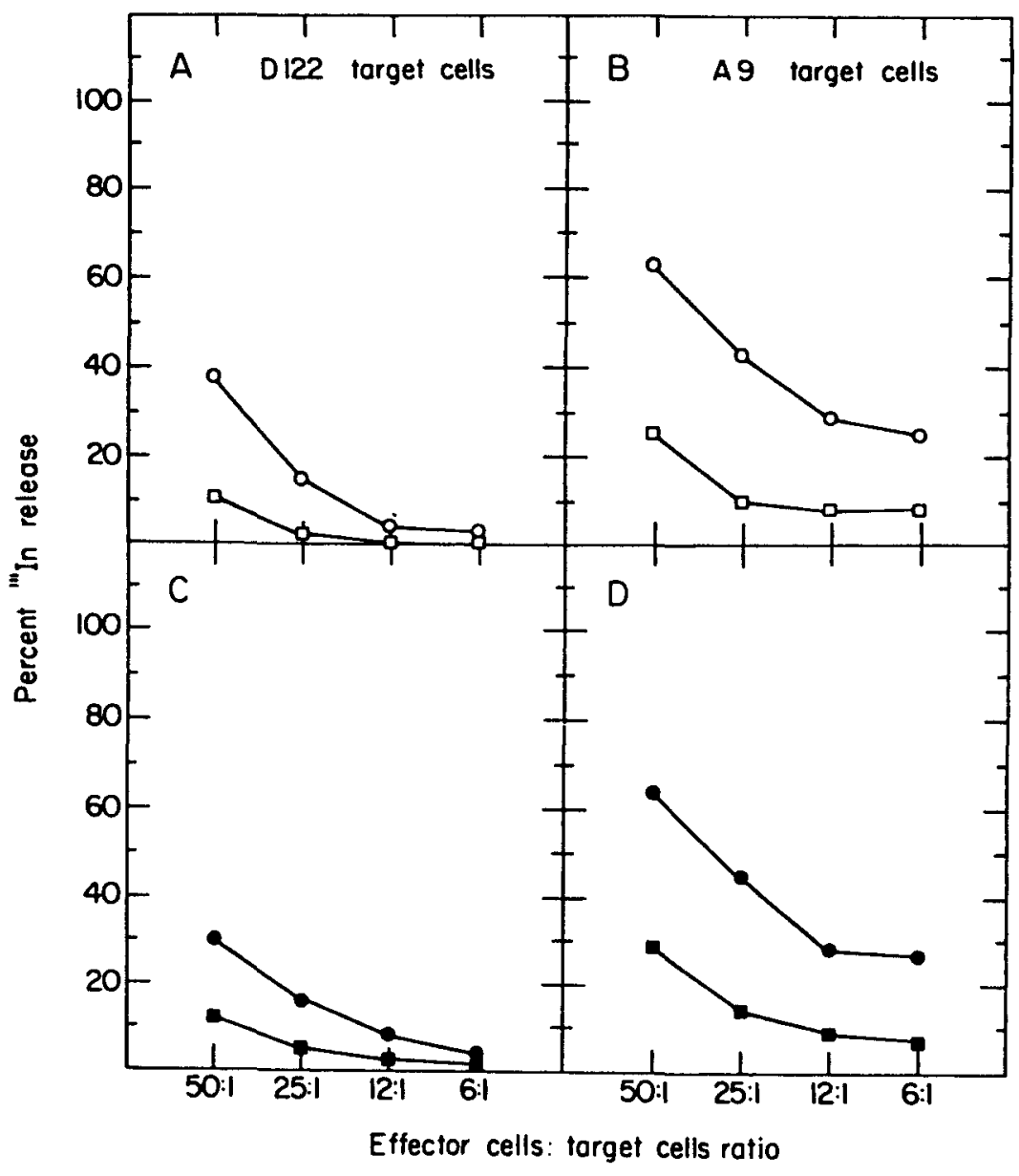

Fig. 2A-D. Correlation of $H-2 K$ gene expression on 3LL clones with ability to stimulate cytotoxicity and susceptibility to cell-mediated cytolysis. C57BL/6J mice were immunized intradermally with $5 \times 10^{4}$ A9 cells $(\bullet-\bullet)$, $1 \times 10^{5} \mathrm{~A} 9$ cells $(\mathrm{O}-\mathrm{O}), 5 \times 10^{4}$ D122 cells ( $\square$ ), or $1 \times 10^{5}$ D122 cells $(\square-\square)$. On day 12 , spleens were removed and lymphocytes were restimulated in vitro on irradiated and mitomycintreated A9 or D122 cells. Indium111-labeled A9 (B, D) or D122 (A, C) cells reacted with these lymphocytes in a 16-h assay molecules of C57BL/6J spleens. Immunoprecipitation of ${ }^{125} \mathrm{I}$ cell surface-labeled and ${ }^{35} \mathrm{~S}$-methionine-labeled extracts of $\mathrm{A9}$ and D122 clones showed a strict correlation between synthesis and cell surface expression. In D122 and in the parental 3LL cells, but not in A9, synthesis of $\mathrm{K}^{\mathrm{b}}$ molecules was suppressed [6]. The $45 \mathrm{~K}$ proteins precipitated by anti-H-2 $2^{\text {b }}$ serum or monoclonal anti-H-2 $K^{b}$ (from clone A9) were similar in migration to molecules precipitated from C57BL/6J splenocytes, and a $12 \mathrm{~K} \beta 2$-microglobulin molecule was coprecipitated. Separation on lentil-lectin Sepharose showed that most of the $\mathrm{H}-2^{\mathrm{b}}$ encoded proteins were in their glycosylated form [6]. To obtain a better understanding of the transcriptional level of the $K$ gene suppression in metastatic clones, we used Northern blot hybridization to analyze the mRNA from clones A9, D122, and 3LL as compared to liver mRNA and RNA extracted from metastatic and nonmetastatic clones of another metastatic tumor, the T10 sarcoma (T10 sarcoma is an $F_{1}\left(H-2^{b} \times H-2^{k}\right)$ tumor that expresses only $\mathrm{D}$ end products of the MHC). We used four probes: (a) a genomic $K^{b}, 5^{\prime}$ region probe, H8Pst8 [8]; (b) a cDNA, $H-2^{d}, 3^{\prime}$ region probe, $\mathrm{pH} 2 \mathrm{IIa}$ [9]; (c) a cDNA, $H-2^{d}, 5^{\prime}$ region probe, pH2III [9]; and (d) a human HLA-B9 cDNA probe. All these probes hybridize to both $\mathrm{K}$ and $\mathrm{D}$ end transcripts. Figure 3 shows that the normal $\mathrm{H}-2$ transcript of 2 $\mathrm{kb}$ that is expressed in the liver is also expressed at a high level in clone A9 and in the 3LL line. A lower level of transcription of the $2-\mathrm{kb}$ mRNA is observed in clone D122 and in the T10 sarcoma clones, as both D122 and all T10 clones lack expression of $\mathrm{K}$ end products. Besides the normal 2-kb transcripts, an abnormal RNA of $5.5-6 \mathrm{~kb}$ was observed in all tumor clones [10]. This transcript hybridized to the three $5^{\prime}$ region probes but not to the $3^{\prime}$ region probe. The origin of this large RNA is not yet known, but it may result from the insertion of a foreign DNA into the $H-2 K$ gene of the tumors. In this event the large RNA could represent a transcript contain- 

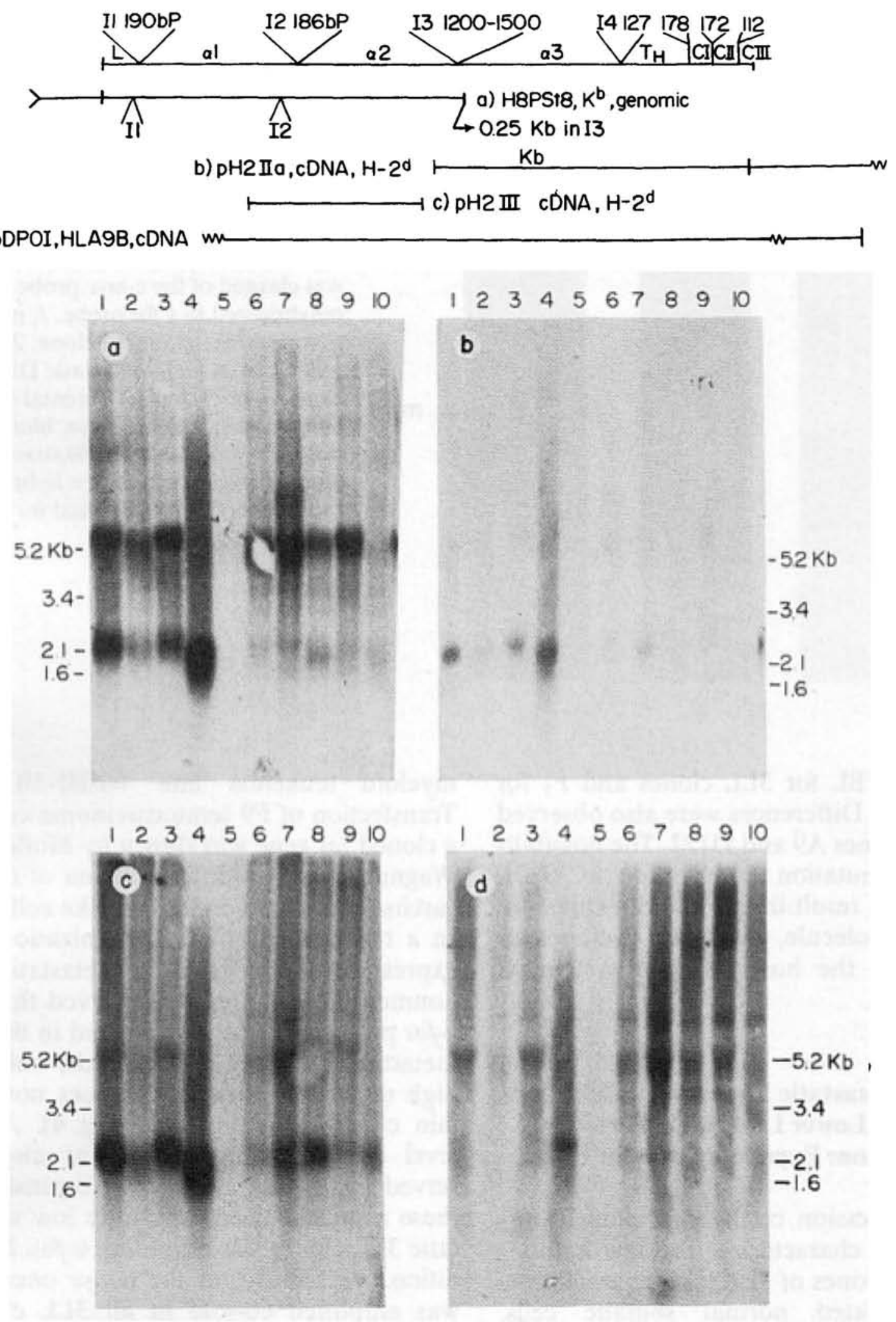

ing $\mathrm{H}-2$ sequences plus other sequences, and this could explain the inactivation of the $H-2 K$ gene.

Southern blot analysis, although very complex, revealed new fragments hybridizing to the $\mathrm{H}-2$ probes when the genomic DNA from tumor clones was digested with EcoRI, BamHI, XbaI, or SStI and compared with liver DNA of the same mouse
Fig. 3a-d. Transcription of MHC class I genes in tumor clones. Northern hybridization performed with poly $(\mathrm{A})^{+}$RNAs from $3 \mathrm{LL}$ carcinoma and T10 sarcoma. 1 , A9, low metastatic, 3LL; 2, D122, high metastatic, 3LL; 3, 3LL, parental; 4, liver; 5, IC9, nonmetastatic, T10; 6 , D6 moderately metastatic, T10; 7, IB9, high metastatic, T10; 8, IE7, high metastatic, T10; 9 and 10 , T8, T40, parental T10. Probes used: a H8PSt8, b $\mathrm{H}-2 \mathrm{II}$, $\mathbf{c} \mathrm{H}-2 \mathrm{III}$, and $\mathbf{d} \mathrm{PDPOI}$ 


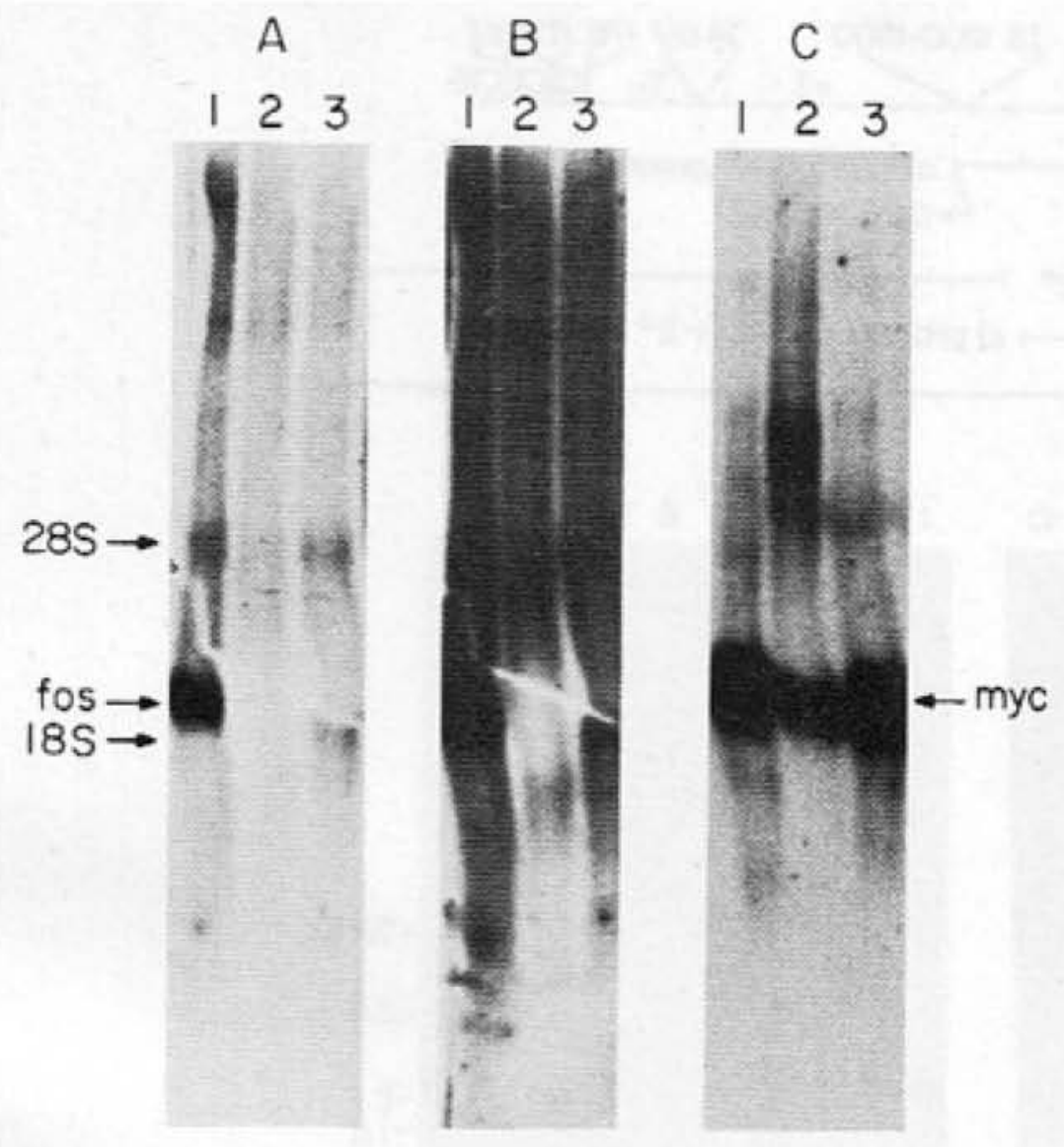

Fig. 4A-C. Expression of c-myc and c-fos onc genes in 3LL clones. Polyadenylated mRNA was selected on oligo-dT cellulose and electrophoresed on formaldehyde-agarose gels. RNA was then transferred onto nitrocellulose filters which were subsequently hybridized with a ${ }^{32} \mathrm{P}$-labeled nicktranslated c-myc probe, washed, and exposed to $x$-ray film. The same blot was cleaned of the c-myc probe and rehybridized to a fos probe. 1, mRNA from low metastatic A9 clone; 2, mRNA from high metastatic D122 clone; 3, mRNA from parental 3LL line. a Hybridization to fos, blots exposed for 1 day; $\mathbf{b}$ hybridization to fos, blots exposed for 3 days; $\mathbf{c}$ hybridization to $m y c$, blots exposed for 1 day strains (C57BL for 3LL clones and $F_{1}$ for T10 clones). Differences were also observed between clones A9 and D122. The possibility that a mutation or insertion in $H-2 \mathrm{~K}$ genes might result in the loss of expression of an H-2 molecule, giving rise to clones insensitive to the host immune system, is investigated.

\section{F. The Metastatic Phenotype Might Represent a Lower Level of Molecular Differentiation: Expression of c-fos Gene}

The co-expression of the two class I antigens, which characterizes the low or nonmetastatic clones of $3 \mathrm{LL}$, also characterizes most nucleated normal somatic cells, whereas both early embryonal cells and nondifferentiated teratocarcinoma cells lack expression of H-2 molecules. Do other gene products of the metastatic versus the nonmetastatic phenotypes signify differences in state of differentiation? Of particular interest from this viewpoint is the fos gene. Expression of c-fos, the cellular counterpart of the FBJ osteosarcoma viral onc gene, was shown to correlate with the induction of differentiation in human myeloid leukemia line WEHI-3B [11]. Transfection of F9 teratocarcinoma cells by a cloned fos gene was shown by Muller and Wagner to induce differentiation of teratocarcinoma cells to endoderm-like cells [12]. In a recent study of the organization and expression of onc genes in metastatic and nonmetastatic clones we observed that the c-fos proto-onc gene is expressed in the low metastatic clone $\mathrm{A} 9$ at high levels, while the high metastatic clone D122 does not contain c-fos-related m-RNA (Fig. 4). A low level of c-fos transcription was also observed in parental 3LL cells. Expansion of these results showed that other low metastatic 3LL clones also expressed c-fos. In addition, we found that the c-myc oncogene was amplified 60 -fold in all $3 \mathrm{LL}$ clones. Thus, the level of c-myc mRNA is very high in A9 and D122 clones, as well as in the parental 3LL line. Figure 4 demonstrates, using the same Northern blot, that while c-myc is expressed in all three cell types, c-fos is expressed mainly in the low metastatic A9 clone.

Is the expression of fos gene product and a full expression of $\mathrm{H}-2 \mathrm{~K}$ and $\mathrm{H}-2 \mathrm{D}$ gene products an indication of a more differentiated state of the A9 low metastatic clone 
than of the metastatic D122 clone, and is such a differentiation step crucial in the control of metastatic spread by the host? We are currently investigating these questions.

Acknowledgments. This investigation was supported by PHS grant no. CA 28139 awarded by the National Cancer Institute, DHHS, USA.

\section{References}

1. Isakov N, Feldman M, Segal S (1981) Control of progression of local tumor and pulmonary metastases of the 3LL Lewis lung carcinoma by different histocompatibility requirements in mice. J N C I 66:919

2. Isakov N, Feldman M, Segal S (1982) An immune response against the alloantigens of the 3LL Lewis lung carcinoma prevents the growth of lung metastases but not of local allografts. Invasion and Metastasis 2:12

3. Isakov N, Katzav S, Feldman M, Segal S (1983) Lewis lung carcinoma cells possess immunogenic $\mathrm{H}-2 \mathrm{D}^{b}$ region gene products but lack $\mathrm{H}-2 \mathrm{~K}^{\mathrm{b}}$ region products. J N C I 71:139

4. Fidler IJ, Kripke ML (1977) Metastasis results from pre-existing variant cells within a malignant tumor. Science 197:893

5. Ozato K, Sachs DH (1981) Monoclonal antibodies to MHC antigens. Hybridoma antibodies reacting to antigens of $\mathrm{H}-2^{\mathrm{b}}$ haplotype reveal genetic control of isotype expression. $\mathrm{J}$ Immunol 126:317

6. Eisenbach L, Segal S, Feldman M (1983) MHC imbalance and metastatic spread in Lewis lung carcinoma clones. Int $\mathbf{J}$ Cancer 32: 113

7. Eisenbach L, Hollander N, Greenfeld L, Yakor H, Segal S, Feldman M (1984) The differential expression of $\mathrm{H}-2 \mathrm{~K}$ versus $\mathrm{H}-2 \mathrm{D}$ antigens, distinguishing high-metastatic from low-metastatic clones, is correlated with the immunogenic properties of the tumor cells. Int J Cancer 34:567

8. Weiss E, Golden L, Zakut R et al. (1983) The DNA sequence of the $\mathrm{H}-2 \mathrm{~K}^{\mathrm{b}}$ gene: Evidence for gene conversion as a mechanism for the generation of polymorphism in histocompatibility antigens. EMBO J 2:453

9. Steinmetz M, Erelinger JG, Fisher D et al. (1981) Three cDNA clones encoding mouse transplantation antigens: Homology to immunoglobulin genes. Cell 24: 125

10. Eisenbach L, Hollander N, Segal S, Feldman $M$ (1985) The differential expression of class I major histocompatibility complex antigens controls the metastatic properties of tumor cells. Transplantation Proc 17:729

11. Gonda TJ, Metcalf D (1984) Expression of myb, myc and fos proto-oncogenes during the differentiation of a murine myeloid leukaemia. Nature 310:249

12. Muller R, Wagner GF (1984) Differentiation of F9 teratocarcinoma stem cells after transfer of c-fos proto-oncogenes. Nature 311:438 